\title{
Patricia Neville, Janet Frame's World of Books
}

\section{Claire Bazin}

\section{(2) OpenEdition}

\section{Journals}

Electronic version

URL: http://journals.openedition.org/ces/4302

DOI: 10.4000/ces.4302

ISSN: 2534-6695

\section{Publisher}

SEPC (Société d'études des pays du Commonwealth)

\section{Electronic reference}

Claire Bazin, "Patricia Neville, Janet Frame's World of Books», Commonwealth Essays and Studies [Online], 43.1 | 2020, Online since 06 November 2020, connection on 10 November 2020. URL : http:// journals.openedition.org/ces/4302 ; DOI : https://doi.org/10.4000/ces.4302

This text was automatically generated on 10 November 2020 .

\section{(c) (i) (9)}

Commonwealth Essays and Studies is licensed under a Licence Creative Commons Attribution - Pas d'Utilisation Commerciale - Pas de Modification 4.0 International. 


\title{
Patricia Neville, Janet Frame's World of Books
}

\author{
Claire Bazin
}

\section{REFERENCES}

Patricia Neville. Janet Frame's World of Books. Stuttgart: Ibidem Verlag, 2019. 234 p. ISBN: 9783838312425 (pb). €34.90

1 Patricia Neville's Janet Frame's World of Books is a fascinating study of Frame's world of words, born from a life-long interest in books and reading. It is a very well documented and illustrated study, based on thorough research and deep familiarity with Frame's works. Neville follows Frame from her childhood as an avid reader and precocious writer (in Dot's Little Folk) to her writing career, in a masterful demonstration that one can become a writer only by having read a lot. In the introduction (made up of three parts), she brings to the fore Frame's abundant use of intertextuality (for the conceptualisation of which she borrows from Kristeva and Barthes), and polyphony (Bakhtin) which the ensuing development analyses and illustrates.

2 The book is divided into six chapters that range from Frame's early readings (novels and poetry) to the varied influences which shaped her writing. Each chapter delves into one or several of Frame's novels or autobiography.

3 The first chapter, entitled "Janet Frame's Books," composed of five sections, is concerned with Frame's exile to Europe in 1956, after her release from the mental hospital of Seacliff the year before. The first section gives an overview of Frame's publishing career both "at home" and abroad (in the US and England more specifically, but also Japan, China, Korea, Turkey, Romania, Slovenia, Spain, Italy, and Germany) and of the translation of her books in different countries. Neville also draws attention to the other media that took their inspiration from Frame's works, such as Jane Campion's film An Angel at My Table - which contributed to making Frame known internationally but also radio drama and even a chamber opera. In the second section, Neville insists 
on the role of Frame's mother (she was a poet herself) in her daughter's literary vocation. But what most developed Frame's taste for writing was undoubtedly Dot's Little Folk, a magazine that encouraged children to publish, often under pseudonyms. Later, in her school days, and during her stays in hospital, she became familiar with the Romantics, Shakespeare, the Brontës and George Eliot, but also Proust, Maupassant, Camus, Mallarmé, the French Nouveau Roman, and Rilke, all of which influenced her writing.

In chapter 2, Neville points to Frame's love of music and sound, which accounts for her valuing poetry as the supreme form of art. Frame's debt to the romantic poets (Blake, Shelley, Yeats, Rilke and Dylan Thomas) is huge, especially as regards their celebration of the natural world, birds in particular, at the expense of modern culture - such themes as Frame develops in her fiction (Living in the Maniototo). Special mention is made of New Zealand poets, in particular Allan Curnow, but also Charles Brasch and Ruth Dallas. The chapter ends on Walt Whitman, whose influence on Frame (in Daughter Buffalo) is of paramount importance, both in style and content.

5 In the following chapter (3), Neville shows the influence of poets and poetry on Frame's fiction, which bears similarities with Baudelaire's "prose-poems," but also with modernist writers, like Joyce, Virginia Woolf, D.H. Lawrence and Faulkner, or poets like Dylan Thomas, G.M. Hopkins, T.S. Eliot, Ted Hughes and Auden. Owls Do Cry is written in poetic prose, typographically rendered through the use of italics. Nature and childhood are given special attention in Intensive Care, Living in the Maniototo and The Edge of the Alphabet. In Towards Another Summer (her posthumous novel), Frame pays retrospective homage to Sylvia Plath (after the latter's suicide) with whom she feels a shared experience of anxiety and despair (see Intensive Care).

6 Chapter 4 is dedicated to the (King James) Bible and its influence on Frame's work, notably in its style, phrasing and syntax, as is particularly apparent in Living in the Maniototo, Faces in the Water, Intensive Care, Daughter Buffalo and The Adaptable Man. Frame's work is influenced not only by the Bible but also by her mother's Christaldelphian, non-conformist faith, and some interest in Buddhism. The Rainbirds combines for instance the story of Lazarus with echoes of Balzac's Colonel Chabert.

7 The following chapter (5) deals with the influence of Shakespeare and of Macbeth in particular: in Faces in the Water, The Adaptable Man but also in Owls Do Cry, A State of Siege, Daughter Buffalo, Living in the Maniototo (which also draws on Thomas Hardy and the Brontës in its depiction of the moors), the Carpathians, The Rainbirds and Scented Gardens for the Blind. Quoting the same books (or even passages) makes repetitions unavoidable, even though the perspective is always different. Neville insists on the presence of water in Frame's works and refers to the influence of Shakespeare's The Tempest which is apparent in an epigraph to the second volume of her autobiography. Frame reveres Prospero's magic of language, of which she makes abundant use in Owls Do Cry, Faces in the Water, A State of Siege and The Edge of the Alphabet. Dreams, too, are legion in the novels, as another sign of Shakespeare's "presence."

8 The last chapter (6) is concerned with myths, oral culture, folk tales, fairy tales, Māori myths and culture (Living in the Maniototo and The Carpathians), and legends (St Cuthbert in The Adaptable Man). Neville quotes Frame's book for children Mona Minim and the Smell of the Sun, which, not unlike traditional fairy-tales, bears a dark side. Neville links myths and survival, stressing the inestimable value of memory (The Carpathians, Scented Gardens for the Blind), to conclude on the universality of Frame's work. 
9 Not only is Neville very familiar with Frame's writings, but she also displays impressive erudition in her knowledge of French, German, American writers, poets and critics as well. She has excavated a mine. This is a very complete, fascinating, innovative and timely work, written in excellent style by a critic who is also undeniably, and like Frame herself, a lover of words. Neville's work contributes to renewing criticism on Frame which has tended up to now to neglect this crucial aspect of her work.

\section{AUTHORS}

\section{CLAIRE BAZIN}

Paris Nanterre University

Claire Bazin is Professor of nineteenth-century British and twentieth-century Commonwealth Literatures. She has published two books on the Brontës, a book on Janet Frame, and a number of articles (on the Brontës, Dracula, Frankenstein, Janet Frame). 